From the preceding brief account, it would seem that the new 'Polaroid' is likely to require most serious consideration not only for students' use but also for research microscopes. Not only is there a substantial saving in cost if the material can be supplied at a similar price to the nicol prism or lower, but improvements are also possible in the optical system and in the microscope design.

\section{THE MELLON INSTITUTE}

\section{WAR-TIME RESEARCH}

$\mathrm{U}$ NDER the title "The Mellon Institute in the Second Year of War", a brief summary of the activities of the Mellon Institute has been condensed. from the thirty-first annual report, indicating its contribution to the war effort. During the year, March 1, 1943-March 1, 1944, a multiple industrial fellowship on chain welding and metallurgy was divided into two separate fellowships on chain welding and on powder metallurgy techniques. The iodine fellowship was revived in April, and seven other proposals for research have been accepted. The Institute's industrial research staff now consists. of 201 fellows and 214 fellowship assistants. Two of these fellowships have been active for thirty years, seven for twenty-five and eight for twenty; sixty in all have concluded at least five years of research. During the year the Institute's expenditure for pure and applied research amounted to 1,652,539 dollars. A new fellowship for research in the wood-container field is concermed to improve standards and production practices for shipping containers and also to eliminate the enormous amount of wood waste in the conversion of trees to such containers of finished lumber. A fellowship has been established to improve cotton fibres by altering the chemical structure without loss of identity or workability of the fibres, and another fellowship will conduct broad basic studies of the physical and chemical properties of cotton. A new fellowship of the Copperas Co. is devoted to studies of the oxidation products of major aromatics from tars.

Nine fellowships) (were ?completed during the year; they covered air-pollution control, antiicing, garments, naphthalene chemistry, pasteurization, pencil technology, surgical supplies, synthetic rubber and tar treatment. Work on air-pollution control was brought to a temporary end through the death of the incumbent fellow. A report has been published on studies under the synthetic rubber fellowship of the toxicity of butadiene carried out for the Rubber Reserve Co.

The Institute's Department of Research in Pure Chemistry directed its efforts chiefly towards chemotherapy. Results obtained with certain new drugs as antimalarial agents are sufficiently encouraging to warrant further research. Under a scheme promoted by the National Research Council, arrangements have been made for evaluating the anti-malarial activity of new drugs. More than eighty new drugs have been submitted for antimalarial appraisal, and efforts have been directed towards possible ways of diminishing the toxicity of chemical structures recognized as possessing anti-malarial potentialities. Investigations on problems in the preparation of cinchona alkaloid derivatives with anti-pneumococcal potency have been terminated and the results published. Proto- types of a new class of modified cinchona derivative in which the phenolic hydroxyl group of apocupreine is replaced by an alkylamino constituent have been prepared by the Bucherer reaction, but the therapeutic action was not increased. A method has been evolved for the preparation of $p$-toluenesulphonyl esters of phenols and alcohols rapidly, economically and in high yield. A publication from the Department and the Department of Chemistry of the University of Pittsburgh deals with cis-3:6-endomethylene- $\Delta$-4-tetrahydrophthalic acid: the anhydride of the corresponding hexahydrophthalic acid has been obtained quantitatively by direct catalytic hydrogenation under high pressure. The synthesis of 3-benzoyl-nor-camphane-2-carboxylic acid by a Friedel-Crafts reaction has been worked out.

Referring to researches proceeding in the Institute under the industrial fellowships, the report states that friction losses in vaned elbows of asbestos ducts have been determined in numerous designs; and the physical and chemical treatment of gypsum, which has received very thorough investigation during the past five years, has yielded especially valuable results in 1942-43. There are eight fellowships in all in the field of ceramics. Thirteen fellowships have been concerned with metallurgical studies and the failure of restrained welds; and the destructive testing of structural joints, involving special gaskets, has received much attention. Systems have been developed for centralized filtration of machine-tool coolants and a differential solubility process for treating waste pickle-liquor is announced. A research programme on the hydrogenation, dehydrogenation, oxidation and alkylation of coal products has been widened considerably, and several new catalytic processes are under development. A new process for ethylbenzene has been put into operation on the large scale, and another investigation has been concerned with the effect of paraffins on the nitration of toluene.

In addition to basic research on the production of phenols, another group is working on the separation of cresols and xylenols from their mixtures; new naphthalene derivatives are also receiving much attention. Studies of the rheological properties of bituminous materials have been continued, and substantial progress has been made in improving fractional distillation techniques under extremely high vacuum.

Under the seven fellowships pertaining to major problems of the food industry, improvements have been effected in dehydrating prepared foods, and new knowledge has been gleaned on decolorizing absorbents, including the evolution of a new synthetic granular absorbent for the sugar industry. In the textile field, the weathering of treated fabrics used as covers over the guns of coastal defences has been investigated to secure textiles more resistant to sun, salt air, wind and rain, and new yarns have been prepared from soya bean protein alone and with viscose, as well as a synthetic textile lubricant for the woollen industry. Reference is also made to advances in processing animal fibres used in felt and the co-relation of physical properties with felt quality. $G R-S$ latex has been applied commercially to the saturation of sulphite papers, with results indicating a satisfactory comparability with rubber latextreated papers but with somewhat less tensile strength. Growing attention to cyclopentadiene has greatly stimulated research on methods for its utilization. Compounds of interest for the manu- 
facture of synthetic resins, rubbers and fibres have been prepared electrolytically and a new curable liner for container closures. New techniques have been developed for the preparation of vinyl resin coating compositions, and a thorough investigation made of the production, purification and analysis of butadiene and styrene by the multiple industrial fellowship on tar synthetics. Other studies have been concerned with specifications for metals for the construction of butadiene and styrene plant. Fundamental work has also been done on the physical chemistry of the purification of raw materials for synthetic rubber. The polymerization of butadiene, styrene and acrylonitrile are under close scrutiny, and new tests for the adhesive properties and ageing characteristics of paints and for the rheological pro. perties of elastomeric adhesives have been adopted as guides in the development of new adhesives, while several new formulæ for 'Cellophane'-tape adhesives have been derived.

Other fellowships have been concerned with protective coatings. Several papers were published on the basic aspects of anti-fouling paint performance. Exhaustive studies of a possible accelerated corrosion effect from accidental or deliberate contact of steel hulls with the anti-fouling paint have indicated that appreciable acceleration can occur under the usual type of anti-fouling compositions containing heavy metals. The production of alkylene polyamines is being delineated precisely for industrial applications, and promising products for the synthesis of motor fuel, for the preparation of chemicals for synthetic rubber and as ingredients for lubricants, paints and insecticides have been developed from investigations on nickel compounds and eatalysts. An insecticide which has given a 98 per cent kill of houseflies in the Peet-Grady chamber has been developed. Several new organic iodine compounds have been prepared in a search for improved iodine antiseptics. Work on intermediates for sulpha drugs has kept pace with current advances in this field.

Studies on the toxicity of several new products and of materials the health hazards of which were unknown but all used by the military forces or government contractors, such as dioctyl phthalate, lowtemperature and extreme-pressure lubricants, insect repellents and cable-impregnating compounds have been completed.

Special reference is made to the work of the Industrial Hygiene Foundation, a non-profit association of industries for the maintenance and advancement of healthy working conditions, which has its headquarters and a multiple fellowship at the Mellon Institute. This Foundation has continued its investigation of sickness absenteeism commenced in 1941. It has given some attention to the placing of disabled soldiers who are returning to the United States and has conducted some fifty plant hygiene surveys, including exposures to such substances as synthetic resin dust, trichloroethylene, hydrogen fluoride, carbon tetrachloride, and excessive temperatures. The Foundation has continued to support medical investigations at the Saranac, New York, Laboratory under L. U. Gardner, covering disability through silica compounds and the effect of aluminium therapy. A grant was also made by the Foundation during the year for a plant investigation of health problems of women in industry. Publications on health problems of women in industry as well as on putting the disabled soldier back to work have been issued during the year.

\section{FORTHCOMING EVENTS}

\author{
Tuesday, September 19
}

Institute of PHYsics (EleCtronics GrodP) (at the Royal Institution, 21 Albemarle Street, London, W.1), at 5.30 p.m.-Dr. A. Sommer "Prineiples of Photo-Electric Emission and their Application in PhotoElectric Cells".

\section{Wednesday, September 20}

INSTITUTE OF METALS (at the James Watt Memorial Institute, Great Charles Street, Birmingham), at 2.15 p.m.-Thirty-sixth Annual Autumn Meeting. Discussion on "Melting and Casting of Bronze". PhYSTCAL SOCIETY (Colour Group) (at the Lighting Service Bureau, E.L.M.A., 2 Savoy Hill, Strand, London, W.C.2), at 3.30 p.m.-Mr. H. G. W. Harding : "Illuminants for Colorimetry and the Colours of Total Radiators"

\section{Friday, September 22}

Institution of Naval ARohitects (joint meeting with the INSTITUTION OF ENGINEERS AND SHIPBUILDRRS IN SCOTLAND) (at 39 Elmbank Crescent, Glasgow), at 2 p.m.-Dr. J. Foster King: "Longitudinal Bending Moments"'; Dr. J. Tutin : "Methods of Levying Shipbuilding".

\section{Saturday, September 23}

BRITISH PEY y hological SocIETY (at the London School of Hygiene and Tropical Medicine, Keppel Street, London, W.C.1), at 2.30 p.m.-gress" (Papers in comment by Dr. Karl Mannheim and Dr. R. H. Thouless).

\section{APPOINTMENTS VACANT}

APPIICATIONs are invited for the following appointments on or before the dates mentionfd:

ResPoNSIBLE LECTURER IN Physiology-The Principal, Chelsea Polytechnic, Manresa Road, London, S.W.3 (September 20).

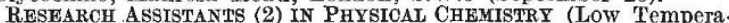
ture Polymerization)-The Registrar, The University, Manchester 13 (September 20).

ASSISTANT LECTCRER (temporary) IN MATHEMATICS-The Secretary and Registrar, The University, Bristol (September 20). RESEAROH ASSISTANT (male, temporary) in the Agricultural EntomoThe Assistant Secretary (Establishments), Ministry of Finance, Stormont, Belfast (September 21).

BIOchemist (Reference No. F,2841.A), and a PHYsicat CHEMIS! (Reference No. F.2842.A.) at the Cereals Researeh Station, St. Albans -The Ministry of Labour and National Service, Room 432 , Alexandra House, Kingsway, London, W.C.2 (quoting the appropriate Reference Ho.) (September 23). TEACHER OF MATHEMatics in the Newton Heath Technical School-
The Director of Education, Education Offices, Deansgate, ManThe Directoin of Education

QUALIFI CIVIL OR MEChanical ENGINERR to teach Mechanical QUALIFIED CIVIL OR MECHANICAL ENGINEER to teach Mechanical
and Constructional Drawing-The Director of Education, The Polytechnic, Regent Street, London, W.1 (September 25).

technic, Regent Street, London, W.1 (September 25). by the Sudan Government Irrigation Department-The Ministry of Labour and National Service, Room 432, Alexandra House, Kingsway, London, W.C.2 (quoting Reference No. E.1114.A) (September 25). Thacher (full-time, gradua te) OF ENGINEERING for Day and EvenCounty Education Offices, City Road, Chester (September 26).

ELECTRICAI، ENGINEER for the Nigerian Government Public Works Department--The Ministry of Labour and National Service, Room 432, Alexandra House, Kingsway, London, W.C.2 (quoting Reference No. D.926.A) (September 26)

FIRST-CLASs ENGINEER to assist in Steam Turbine Design, Research and Development (location, Midlands)-The Ministry of Labour and National Service, Room 432, Alexandra House, Kingsway, London W.C.2 (quoting Reference No. C.2166.XA) (September 26).

Charr of MINING-The Acting Registrar, The University, Leeds 2 (September 30).

DIRECTOR OF RESEAROH, Forest Products Research Laboratory Princes Risborough-The Secretary, Department of Seientiflc and Industrial Research, Teddington, Middx. (October 9).

ASSISTANT TEOHNICAL EXAMINING OFFICERS (temporary) in the Victualling Department of the Admiralty-The Ministry of Labour and National Service, Room 432, Alexandra House, Kingsway, London, W.C.2 (quoting Reference No. F.2911.A) (October 11).

LeCTUR IN PHILOSOPHY - The Very Rev. the Dean, Christ Church, Oxford (October 15).

ELDER PROFESSORSHIP OF ANATOMY AND Histologr in the Univer. sity of Adelaide-The Secretary, Universities Bureau of the British Empire, c/o University College, Gower Street, London, W.C.1 (October 31).

DIRECTOR OF THE DEPARTMENT OF SOCIAL STUDIES, University of Sydney-The Secretary, Universities Bureau of the British Empire, c/o University College, Gower Street, London, W.C.1 (Sydney, December 1)

READFR IN STATISTIOS who will also act as Director of the Institute of Statistics - The Registrar, University of Oxford, Old Clarendon Building, Oxford.

ASSISTANT MECHANIOAL ENGINEER for the Electrical Branch of the Nigerian Government Public Works Department-The Secretary, Overseas Manpower Committee, Ministry of Labour and Nationa Reference No, 1391). 